\title{
OPEN Retraction Note: Increased biomass productivity in green algae by tuning non-photochemical quenching
}

\author{
Silvia Berteotti*, Matteo Ballottari* \& Roberto Bassi \\ Retraction of: Scientific Reports https://doi.org/10.1038/srep21339, published online 18 February 2016 \\ The Authors retract this Article.
}

Following the publication of this study, we repeated the experiments described in the Article, but could not replicate the results. We were unable to reproduce the strong increase in light use efficiency reported for the npq4 genotype in any condition despite using the same instrumentation and genotypes as in the published study. We have not been able to identify the reasons for the lack of replication and we are retracting the study as we cannot guarantee the accuracy of the conclusions.

$\mathrm{MB}$ and $\mathrm{RB}$ agree with the retraction of this Article, SB could not be reached.

(c) (i) Open Access This article is licensed under a Creative Commons Attribution 4.0 International cc. License, which permits use, sharing, adaptation, distribution and reproduction in any medium or format, as long as you give appropriate credit to the original author(s) and the source, provide a link to the Creative Commons license, and indicate if changes were made. The images or other third party material in this article are included in the article's Creative Commons license, unless indicated otherwise in a credit line to the material. If material is not included in the article's Creative Commons license and your intended use is not permitted by statutory regulation or exceeds the permitted use, you will need to obtain permission directly from the copyright holder. To view a copy of this license, visit http://creativecommons.org/licenses/by/4.0/.

(C) The Author(s) 2019

Università di Verona, Dipartimento di Biotecnologie, Strada le Grazie 15, 37134, Verona, Italy. *These authors contributed equally to this work. Correspondence and requests for materials should be addressed to R.B. (email: roberto.bassi@univr.it) 